DOE/MC/31147-96/C0509

(and 26042)

Filter Component Assessment

Authors:

Mary Anne Alvin

Thomas E. Lippert
Edward S. Diaz

Eugene W. Smeltzer

\title{
Contractor:
}

Westinghouse Electric Corporation

Science and Technology Center

1310 Beulah Road

Pittsburgh, Pennsylvania 15235-5098

Contract Number:

DE-AC21-89MC31147

DE-FC21-89MC26042

\section{Conference Title:}

Advanced Coal-Fired Power Systems '95 Review Meeting

\section{Conference Location:}

Morgantown, West Virginia

\section{Conference Dates:}

June 27-29, 1995

\section{Conference Sponsor:}

U.S. Department of Energy, Morgantown Energy Technology Center (METC) 


\section{DISCLAIMER}

This report was prepared as an account of work sponsored by an agency of the United States Government. Neither the United States Government nor any agency thereof, nor any of their employees, makes any warranty, express or implied, or assumes any legal liability or responsibility for the accuracy, completeness, or usefulness of any information, apparatus, product, or process disclosed, or represents that its use would not infringe privately owned rights. Reference herein to any specific commercial product, process, or service by trade name, trademark, manufacturer, or otherwise does not necessarily constitute or imply its endorsement, recommendation, or favoring by the United States Government or any agency thereof. The views and opinions of authors expressed herein do not necessarily state or reflect those of the United States Government or any agency thereof.

This report has been reproduced directly from the best available copy.

Available to DOE and DOE contractors from the Office of Scientific and Technical Information, 175 Oak Ridge Turnpike, Oak Ridge, TN 37831; prices available at (615) 576-8401.

Available to the public from the National Technical Information Service, U.S. Department of Commerce, 5285 Port Royal Road, Springfield, VA 22161; phone orders accepted at (703) 487-4650. 


\section{$3.5 \quad$ Filter Component Assessment}

\section{CONTRACT INFORMATION}

Contract Number

Contractor

Contractor Project Manager

Principal Investigators

\section{METC Project Manager}

Period of Performance

Schedule and Milestones
DE-AC21-94MC31147

DE-FC21-89MC26042

Westinghouse Electric Corporation

Science \& Technology Center

1310 Beulah Road

Pittsburgh, PA 15235-5098

(412) 256-2066 (Telephone)

(412) 256-2121 (Telefax)

Mary Anne Alvin

Mary Anne Alvin

Thomas E. Lippert

Edward S. Diaz

Eugene E. Smeltzer

Richard A. Dennis

September 15, 1994 - December 14, 1996

FY 95 Program Schedule

$\begin{array}{llllllllllllll}\text { TASK } & S & O & N & D & J & F & M & A & M & J & J & A\end{array}$

Test Plan

Filter Characterization

Mechanical Durability

Corrosion Resistance

Additional Testing

\section{OBJECTIVES}

The objectives of this program are to provide a more "ruggedized" filter system that utilizes porous ceramic filters which have improved resistance to damage resulting from crack propagation, thermal fatigue and/or thermal excursions during plant or process transient conditions, and/or mechanical ash bridging events within the candle filter array. 


\section{BACKGROUND INFORMATION}

Characterization of the monolithic alumina/mullite and clay bonded silicon carbide candle filter materials after 716 and 1341 hours of operation in the Westinghouse Advanced Particulate Filtration (W-APF) system at the Ahlstrom pressurized circulating fluidized-bed combustion (PCFBC) test facility in Karhula, Finland, as well as after 5855 hours of operation at the pressurized fluidized-bed combustion (PFBC) test facility at the American Electric Power (AEP) Tidd Demonstration Plant in Brilliant, Ohio, indicated that the porous ceramic filters typically lose strength at process operating conditions until a "conditioned" state is achieved. These materials also experienced numerous phase changes within the bulk matrix or binder phases, which reflected a response to both process operating temperature and flue gas chemistry. ${ }^{(1,2)}$ Microcrack formations have been identified frequently within the alumina/mullite filter matrix, and are also expected to occur within the binder phase and silicon carbide grains in the clay bonded filter materials.

In order to provide a more "ruggedized" filter system, development of porous ceramic filters has been undertaken to produce filters with improved creep resistance, fracture toughness, and oxidation or corrosion resistance for extended use in either advanced coal-fired combustion or gasification process applications. Several manufacturers have developed, or are in the process of developing, chemically vapor infiltrated (CVI) candle filters which are expected to have "improved" fracture toughness characteristics. Improved toughness characteristics are considered to mitigate crack propagation through the porous ceramic matrix, which ultimately minimizes catastrophic failure, particularly under thermal fatigue and/or shock conditions during process operation. CVI toughened materials typically include the use of both oxide and nonoxide continuous fiber ceramic composites (CFCCs).

In recent developmental and prototype CFCC filter manufacturing efforts which involve the use of nonoxide CFCCs, the stability and oxidation resistance of the fiber/matrix interface are considered to be potential issues limiting high temperature use. Although the nonoxide CFCCs exhibit nonbrittle failure characteristics and have sufficient room temperature mechanical proprieties, the mechanical properties of the nonoxide CFCCs may degrade as a result of oxidation of the interface layer during exposure to high temperature $\left(>800^{\circ} \mathrm{C}\right)$ in an oxidizing environment. When this occurs, the CFCC matrix will exhibit brittle characteristics. In the development of an oxide-based CFCC matrix, key issues which remain to be resolved are the production of oxide fibers with improved high temperature capabilities, particularly under low stress (i.e., 5-15 ksi) loads, as well as the development of functional interface coatings which toughen the nonbrittle oxide CFCC matrix.

Alternate manufacturers have or are in the process of developing similar fracture toughened materials which utilize solgel and/or chemical vapor composite (CVC) techniques to form potentially less expensive fiber, felt or mat, whisker or particulate reinforced, oxide and nonoxide ceramic composites. The concept of utilizing a single phase matrix also has merit in the production of porous ceramic filter elements, since phase transformations frequently result during process operation which potentially lead to a mismatch in the thermal coefficient of expansion of the various resulting phases. Alternately the inclusion of conductive phases (i.e., SiC) within oxide-based ceramic matrices has been considered.

As with current filter materials, the advanced or second generation filter materials are required to achieve reliable long-term service use, as well as 
be reproducibly manufactured during large volume production (i.e., 500-1000 filter elements). The criteria for reliable, long-term service operation conceivably includes a minimum of $10,000-25,000$ hours of maintenance-free life; 10-20 emergency shutdowns during which time the ceramic filters may experience thermal shock conditions; $>100$ controlled process startups and shutdowns; temperature excursions of up to $\sim 1000-1200^{\circ} \mathrm{F}$; cleanability of adherent, "sticky" or adhesive ash cake layers; resistance to fracture and catastrophic failure during ash bridging events; and chemical and phase stability during exposure to corrosive alkali, sulfur, or chloride gas, liquid, or condensed phase species. In order to "design" and manufacture ceramics which are capable of withstanding the service operating criteria, material properties, crack resistance $\left(\mathrm{K}_{\mathrm{lc}}\right)$, slow crack growth data, materials with a Weibull modulus of 20 , and preferentially smooth, "nonstick" surface textures are needed. Similarly failure probability calculations, simulated thermal transient testing under steady state, accelerated pulse cycling, and process transient conditions, and corrosion testing, all form the basis of developing reliable, mechanically durable, and chemically stable porous ceramic filters for extended $\mathrm{PFBC}$ and/or integrated gasification combined cycle (IGCC) service use.

\section{PROJECT DESCRIPTION}

As part of the current Phase 1, Task 1, effort of this program, Westinghouse is evaluating the filtration characteristics, mechanical integrity, and corrosion resistance of the following advanced or second generation candle filters for use in advanced coal-fired process applications:

- 3M CVI-SiC composite - chemical vapor infiltration of silicon carbide into an aluminosilicate Nextel $^{\mathrm{rM}} 312$ fiber preform
- DuPont PRD-66 - filament wound candle filter structure containing corundum, cordierite, cristobalite, and mullite

- DuPont SiC-SiC - chemical infiltration of silicon carbide into a silicon carbide Nicalon $^{T M}$ fiber mat or felt preform

- IF\&P Fibrosic ${ }^{T M}$ - vacuum infiltrated oxidebased chopped fibrous matrix.

In Task 1.1, Test Plan and Selection of Prototype Filters, candle filter dimensional tolerance specifications were provided to each filter supplier, identifying the candle filter length; OD dimensions of the flange and candle body; flange radius, geometry, and dimensions; and a preferred candle filter wall thickness along the flange for ease of installation and use with the existing Westinghouse holder/mount design. In addition, specifications relating to the candle filter linearity, concentricity, perpendicularity, asmanufactured pressure drop, and particle collection efficiency were provided to each supplier. Westinghouse similarly required that QA/QC procedures be implemented during the production of each filter batch or lot, in order to assure homogeneity not only among filters produced during a single production firing, but also between various filter production firings. Homogeneity is required not only for the raw materials utilized during the actual manufacturing process, but is also required in terms of resulting strength, porosity, membrane and/or bulk support matrix characteristics, absence of cracks and/or scratches, integrity of the flange and end cap, etc. The presence of patches and/or repairs which produce an out-of-spec body were not considered to be acceptable by the Westinghouse QA/QC dimensional tolerance criteria. Documentation and certification that the initial raw materials and manufacturing process were within the vendor's ISO-9000 standards, and that these had not changed or been modified since delivery of the initial set of filters. Destructive and nondestructive characterization data of the final 
filter production batch(es) were requested to be submitted by each supplier.

As part of Task 1.2, Assessment of Prototype Filter Filtration Characteristics, Westinghouse has assessed the cold permeability and filter production uniformity of the as-manufactured $3 \mathrm{M}$ CVI-SiC composite, DuPont PRD-66, DuPont $\mathrm{SiC}-\mathrm{SiC}$, and IF\&P Fibrosic ${ }^{\mathrm{TM}}$ candle filters. Additional high temperature permeability, filtration efficiency, cleanability, pressure drop characteristics, and fine particle penetration into the advanced candle filter matrices are being evaluated during conduct of steady state, high temperature, high pressure (HTHP) testing in one of Westinghouse's PFBC hot gas filtration systems in Pittsburgh, PA.

In order to assess the mechanical durability of the advanced or second generation candles, the elements were subjected to extended accelerated pulse cycling conditions in the Westinghouse HTHP PFBC test facility as part of Task 1.3, Assessment of Prototype Filter Mechanical Durability. By acquiring -3500 simulated pulse cycles, the possible influence of thermal fatigue on the resulting bulk strength and fracture toughness of the ceramic matrices is identified. Additional HTHP PFBC testing included exposure of the advanced, second generation candle filters to a series of thermal transient events which represented either mild or severe process system temperature excursions that had previously been experienced in pilot plant testing. By monitoring the residual bulk strength, fracture toughness, and microstructure of the filter elements after exposure to the simulated PFBC process transient conditions, a defined process operating regime, as well as plant control requirements, may be identified for viable operation of the advanced, second generation filters.
Previous efforts at Westinghouse have indicated the potential susceptibility of the nonoxide filter matrices to oxidize and/or experience corrosive attack during operation at high temperature, particularly in a steam and/or steam/alkali-containing environment. ${ }^{(3-5)}$ In order to identify the response of the advanced, second generation filter materials to possible gas phase reactions, flow-through testing was conducted in which either mini-candles or discs of the advanced, second generation candle filters were exposed for 400 hours at $870^{\circ} \mathrm{C}$, to either a $5-7 \%$ steam/air or $20 \mathrm{ppm} \mathrm{NaCl} / 5-7 \%$ steam/air gas phase environment, with pulse cycling (Task 1.4, Assessment of Prototype Filter Chemical Resistance). Post-test characterization of the exposed filter matrices has included determination of the residual bulk strength of the material. Additional analyses will include identification of the phase and/or morphology changes that have occurred as a result of exposure of the ceramic filter materials to the high temperature, steam/air and alkali/steam/air, flow-through test environment.

During conduct of the cold permeability, steady-state, corrosion, and/or thermal transient testing, modifications may become apparent which would improve the performance and operating life of the advanced, second generation candle filters. Pending that these modifications can be made to the advanced, second generation filters (i.e., alternate design or material composition, etc.), further testing or re-qualification of the modified filter elements will be undertaken in Task 1.5, Additional Testing of Improved Prototype Filters.

All results generated during conduct of Tasks 1 through 5 in this program will be summarized and presented in a Topical Report (Task 1.6). 


\section{RESULTS}

Since September 1994, efforts at Westinghouse have been focused on identifying the high temperature particulate filtration characteristics, as well as the thermal, mechanical and corrosion stability of four advanced, second generation filter elements. The following sections present a discussion of the filtration characteristics and materials evaluation which have been conducted after bench-scale exposure of the advanced filters at Westinghouse, as well as after 1110-1705 hours of hot gas filtration in the W-APF system at the AEP Power Demonstration Plant in Brilliant, Ohio.

\section{Permeability Measurements}

Manufacture of 1.4-1.5 m advanced, second generation candle filters has been achieved within the past two years. The room temperature, gas flow resistance of the as-manufactured 3M CVISiC composite, DuPont PRD-66, DuPont SiC$\mathrm{SiC}$, and IF\&P Fibrosic ${ }^{\mathrm{TM}}$ candle filters is shown in Figure 1 in conjunction with first generation, monolithic filter elements. These data indicate the relatively high initial permeability of the porous, light weight, second generation filter elements.

\section{As-Manufactured Filter Material Strength}

All four candle filters were characterized in terms of their as-manufactured, compressive and tensile strengths via $\mathrm{C}$-ring and/or O-ring testing at room temperature and at various elevated temperatures which reflect specific process operating conditions. For example, $732^{\circ} \mathrm{C}$ is representative of the nominal W-APF system operating temperature at AEP in Test Segment $\# 4 ;^{(6)} 843^{\circ} \mathrm{C}$ reflects the operating temperature of the Westinghouse HTHP PFBC test facility during accelerated pulse cycling and/or process transient testing; $870^{\circ} \mathrm{C}$ is representative of the Westinghouse flow-through alkali corrosion test temperature. Typically 15 or $25.4 \mathrm{~mm}$ samples are cut from each candle filter using a diamond wheel. The orientation of the C-ring sample notch is rotated around the filter body in order to eliminate any uniaxial processing or manufacturing effects.

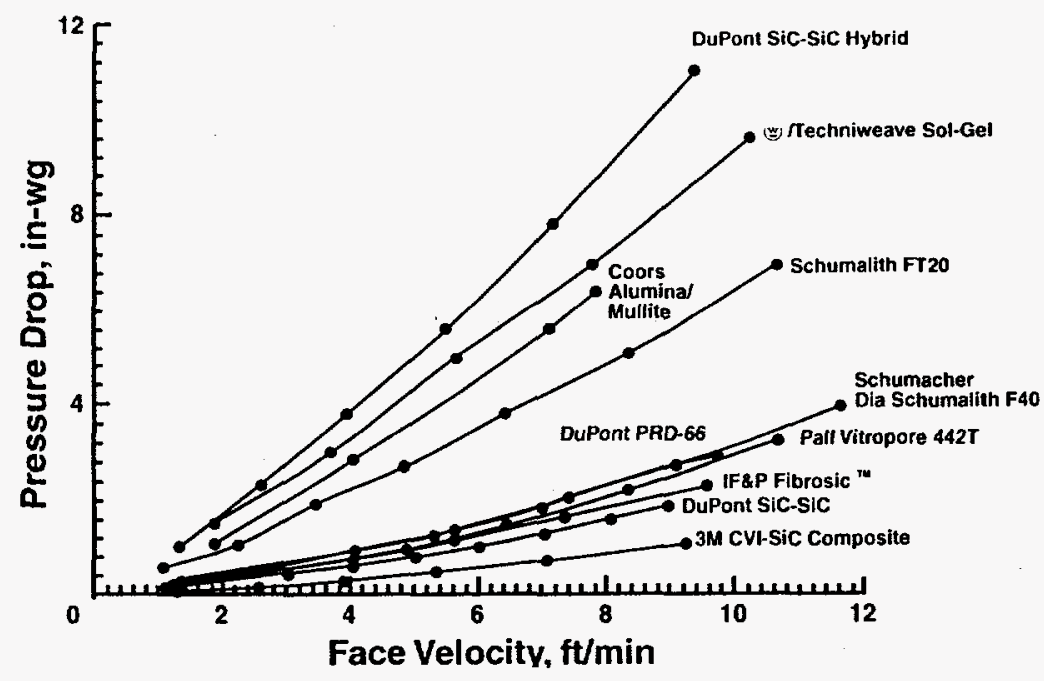

Figure 1. Room Temperature Gas Flow Resistance of the First Generation Monolithic and Advanced Second Generation Candle Filters 
As shown in Table 1, the as-manufactured strengths of the advanced, second generation candle filters vary from being relatively low for the IF\&P Fibrosic ${ }^{\top M}$ matrix, to moderately strong for the filament wound DuPont PRD-66 filter matrix, to extremely strong for the $3 \mathrm{M}$ CVI-SiC triaxial braid and DuPont SiC-SiC composite matrices. Both the applied load to failure and resulting calculated strength vary slightly depending on the whether the sample length is 15 or $25.4 \mathrm{~mm}$, and whether C-ring or O-ring testing is conducted. By adopting a standard sample length (i.e., 15 or $25.4 \mathrm{~mm}$ ) and test methodology, the as-manufactured and field-tested filter strength data can be compared, provided that the filter matrix can be cut as an integral unit. For this reason, Westinghouse has selected to continue testing $15 \mathrm{~mm}$ samples, utilizing predominantly C-ring compressive and tensile testing to monitor changes along the gas contacted outer surface and pulse cycled inner surface of the filter element, respectively, both at room temperature, as well as at process operating temperatures. This test methodology has been shown to be adequate for maintaining the integral nature of all four advanced, second generation filter materials. Limited additional testing is, however, conducted at Westinghouse utilizing either 15 or $25.4 \mathrm{~mm}$ O-rings.

Due to the relatively thin wall construction of the $3 \mathrm{M}$ CVI-SiC and DuPont SiC-SiC composite matrices (i.e., $-3.6 \mathrm{~mm} 3 \mathrm{M}$ composite thickness; $\sim 1.3 \mathrm{~mm} 3 \mathrm{M}$ triaxial support braid thickness; and $\sim 1.6 \mathrm{~mm}$ DuPont composite thickness), the resulting strength of these materials is calculated to be extremely high in comparison to the monolithic or first generation, and alternate advanced or second generation filter elements (Table 2). In contrast, however, the applied load required to fail the $3 \mathrm{M} \mathrm{CVI-SiC}$ and DuPont SiC$\mathrm{SiC}$ composite materials is substantially lower than the applied load required to fail the first generation monolithic materials, but is higher than the applied load needed to fail the IF\&P Fibrosic ${ }^{\top M}$ matrix. Given the applied loads shown in Table 2, failure of either the first generation monolithic or advanced, second generation candles would be expected to result if ash bridging were to occur within a candle cluster or array during process operation.

As-manufactured bulk strength data as a function of temperature are currently being developed for each of the advanced, second generation filter materials. As shown in Table 3, the bulk strength of the DuPont PRD-66 matrix appears to increase as temperature increases. In addition, the resulting load vs deflection curves which are generated for each fiber reinforced filter material during bulk strength testing are being utilized to provide preliminary information regarding the fracture toughness of the various porous ceramic filter matrices.

\section{HTHP Testing}

In order to develop the thermal shock and thermal fatigue characteristics of the advanced, second generation filter elements, testing was conducted in Westinghouse's high temperature, high pressure (HTHP), pressurized fluidized-bed combustion (PFBC) test facility, utilizing arrays which contained all four filter element types. A brief description of the test procedures that were used to evaluate or qualify the filter elements prior to use in field test operations, and general comments regarding the response of the various filter elements to simulated process transients and accelerated pulse cycle testing follow. Post-test residual bulk strength characterization (i.e., C-ring compressive and/or tensile testing at $25^{\circ} \mathrm{C}$ and $843^{\circ} \mathrm{C}$; room temperature burst testing), and scanning electron microscopy/energy dispersive $\mathrm{x}$-ray analysis (SEM/EDAX) are currently being performed on each exposed filter element. The results of these analyses will be reported at a later date. 


\section{Table 1. Load and Ultimate Strength of the As-Manufactured Second Generation Candle Filters}

\begin{tabular}{|c|c|c|c|c|c|c|}
\hline \multirow[b]{2}{*}{ Sample ID No. } & \multicolumn{2}{|c|}{ Room Temperature } & \multicolumn{2}{|c|}{$843^{\circ} \mathrm{C}$} & \multicolumn{2}{|c|}{$870^{\circ} \mathrm{C}$} \\
\hline & Load, Ibs & Strength, psi & Load, Ibs & Strength, psi & Load, Ibs & Strength, psi \\
\hline \multicolumn{7}{|l|}{ 3M CVI-SiC Composite } \\
\hline 43-1-2 C-Ring Compression (15 mm) & 2.5 & $1343(13187)(a)$ & $2.6(b)$ & $1352(13444)(b)$ & TDB & TBD \\
\hline 43-1-2 C-Ring Compression (25.4 mm) & 5.4 & $1635(17012)$ & 5.1 (b) & 1425 (16857) (b) & & TBD \\
\hline \multirow[t]{2}{*}{ 43-1-2 O-Ring Compression (15 mm) } & $7.7 \pm 0.84$ & $1315 \pm 186$ & $5.98 \pm 1.03(b)$ & $1104 \pm 350(b)$ & TBD & TBD \\
\hline & & $(13276 \pm 1417)$ & & $(11250 \pm 3595)(b)$ & & TBD \\
\hline \multirow[t]{2}{*}{ 43-1-2 O-Ring Compression (25.4 mm) } & $13.61 \pm 1.90$ & $1314 \pm 254$ & $10.8 \pm 1.7(b)$ & $1060 \pm 219(\mathrm{~b})$ & TBD & TBD \\
\hline & & $(14026 \pm 2012)$ & & $11012 \pm 1795(b)$ & & TBD \\
\hline \multicolumn{7}{|l|}{ DuPont PRD-66 } \\
\hline D-259 C-Ring Compression (15 mm) & $10.84 \pm 0.41$ & $1325.01 \pm 71.11$ & $12.69 \pm 1.72$ & $1543.35 \pm 196.99$ & $13.29 \pm 0.95$ & $1629.41 \pm 142.14$ \\
\hline D-259 C-Ring Tension (15 mm) & $7.54 \pm 1.77$ & $1195.95 \pm 280.56$ & $7.53 \pm 0.58$ & $1213.25 \pm 93.22$ & $8.73 \pm 1.85$ & $1393.56 \pm 280.96$ \\
\hline D-249 O-Ring Compression (15 mm) & $27.93 \pm 1.93$ & $1064.89 \pm 84.21$ & $30.21 \pm 4.02$ & $1160.89 \pm 197.40$ & $30.08 \pm 3.19$ & $1144.78 \pm 139.90$ \\
\hline D-249 O-Ring Compression (20.4 mm) & $37.21 \pm 3.00$ & $1040.44 \pm 106.19$ & $37.48 \pm 4.75$ & $1033.56 \pm 129.84$ & $41.60 \pm 6.52$ & $1148.56 \pm 173.54$ \\
\hline \multicolumn{7}{|l|}{ DuPont SiC-SiC } \\
\hline D/O C-Ring Compression (15 mm) & $4.12 \pm 0.38$ & $11905 \pm 1556$ & $5.90 \pm 0.80$ & $18518 \pm 2378$ & $5.53 \pm 140$ & $16585 \pm 5220$ \\
\hline D/O C-Ring Tension (15 mm) & $6.48 \pm 0.84$ & $20210 \pm 4139$ & $5.80 \pm 0.86$ & $18811 \pm 3617$ & $6.48 \pm 1.67$ & $20242 \pm 5560$ \\
\hline D/O O-Ring Compression (15 mm) & $18.57 \pm 2.18$ & $16303 \pm 1249$ & $19.73 \pm 2.57$ & $18810 \pm 1374$ & $21.37 \pm 1.12$ & $18902 \pm 652$ \\
\hline D/O O-Ring Compression $(25.4 \mathrm{~mm})$ & $32.63 \pm 8.24$ & $18064 \pm 2156$ & $26.53 \pm 5.78$ & $14887 \pm 271$ & $33.70 \pm 6.61$ & $16226 \pm 252$ \\
\hline \multicolumn{7}{|l|}{ IF\&P Fibrosic ${ }^{\mathrm{M}}$} \\
\hline RX9502-1709 C-Ring Comp (15 mm) & $0.64 \pm 0.12$ & $28.13 \pm 6.70$ & $2.11 \pm 0.41$ & $98.86 \pm 18.69$ & $2.14 \pm 0.59$ & $95.70 \pm 17.58$ \\
\hline RX9502-1709 C-Ring Tension (15 mm) & $0.71 \pm 0.15$ & $50.90 \pm 11.96$ & $1.03 \pm 0.16$ & $70.70 \pm 11.71$ & $1.04 \pm 0.36$ & $74.45 \pm 25.59$ \\
\hline RX9502-1708 O-Ring Comp (15 mm) & $2.62 \pm 0.23$ & $53.22 \pm 5.45$ & $3.24 \pm 0.55$ & $66.56 \pm 9.90$ & $3.62 \pm 0.49$ & $71.67 \pm 12.54$ \\
\hline RX9502-1708 O-Ring Comp (20.4 mm) & $4.03 \pm 0.24$ & $59.33 \pm 7.11$ & $4.74 \pm 0.90$ & $67.56 \pm 15.70$ & $5.36 \pm 0.42$ & $78.67 \pm 9.64$ \\
\hline
\end{tabular}

(a) Three Layer Composite Strength; (Triaxial Braid Support).

(b) Strength Measured At $732^{\circ} \mathrm{C}$; Strengths To Be Determined At Temperatures Of $843^{\circ} \mathrm{C}$ And $870^{\circ} \mathrm{C}$.

TBD: To Be Determined.

Cross-Head Speed of $0.05 \mathrm{in} / \mathrm{min}$ is Consistently Utilized During Conduct of C-Ring Compressive or Tensile Testing. 


\section{Table 2. Comparison of the First and Second Generation As-Manufactured Candle Filter Material Properties}

\begin{tabular}{|c|c|c|c|c|c|c|c|c|}
\hline \multirow{2}{*}{$\begin{array}{l}\text { Filter Matrix } \\
\qquad(15 \mathrm{~mm})\end{array}$} & \multicolumn{2}{|c|}{$\begin{array}{c}25^{\circ} \mathrm{C} \mathrm{C} \text {-Ring Strength, } \\
\text { psi, }\end{array}$} & \multicolumn{2}{|c|}{$\begin{array}{l}25^{\circ} \mathrm{C} \text { C-Ring Ultimate Load, } \\
\text { lbs }\end{array}$} & \multirow{2}{*}{$\begin{array}{l}\text { Burst } \\
\text { Pressure, } \\
\text { psi }\end{array}$} & \multirow{2}{*}{$\begin{array}{l}\text { Ultimate } \\
\text { Hoop } \\
\text { Stress,psi }\end{array}$} & \multirow{2}{*}{$\begin{array}{c}\text { Elastic } \\
\text { Modulus, } \\
\text { psi } \times 10^{\wedge} 6\end{array}$} & \multirow{2}{*}{$\begin{array}{c}\text { Poissons } \\
\text { Ratio }\end{array}$} \\
\hline & Compression & Tension & Compression & Tension & & & & \\
\hline Coors Alumina/Mullite & $2575 \pm 182$ & $2721 \pm 415$ & $42.8 \pm 2.4$ & $31.4 \pm 4.9$ & 860 & 2317 & 5.7 & 0.23 \\
\hline Pall Vitropore $442 T$ & $2857 \pm 186$ & $2574 \pm 177$ & $60.5 \pm 5.9$ & $35.3 \pm 1.8$ & $513-970$ & $1307-2499$ & $5.25-6.67$ & $0.14-0.19$ \\
\hline Schumacher Dia & $1300 \pm 213(a)$ & $1907 \pm 111$ & $74.5 \pm 14.2$ & $53.4 \pm 3.7$ & & & & \\
\hline Schumalith F40 & $1790 \pm 112(b)$ & $2308+275$ & $102.1 \pm 9.4$ & $63.8 \pm 8.2$ & $1140-1370$ & $1893-2267$ & $5.89-6.26$ & $0.25-0.31$ \\
\hline $\begin{array}{l}\text { Schumacher Dia } \\
\text { Schumalith FT20 }\end{array}$ & $2296 \pm 261$ & $2268 \pm 167$ & $44.2 \pm 4.8$ & $29.2 \pm 2.9$ & 665 & 1703 & 7.3 & 0.17 \\
\hline 3M CVI-SiC Composite & $\begin{array}{c}1343(c) \\
13187(d) \\
1315 \pm 186(c) * \\
13276 \pm 1417(d) *\end{array}$ & & $\begin{array}{c}2.5 \\
2.5 \\
7.7 \pm 0.84 \text { * } \\
7.7 \pm 0.84 \text { * }\end{array}$ & & & 1.01 & $2.96-3.38$ & $0.14-0.27$ \\
\hline DuPont SiC-SiC & $\begin{array}{l}11905 \pm 1556 \\
16303 \pm 1249\end{array}$ & $20210 \pm 4139$ & $\begin{array}{c}4.12 \pm 0.38 \\
18.57 \pm 2.18\end{array}$ & $6.48 \pm 0.84$ & & $2972(e)$ & & \\
\hline DuPont PRD-66 & $1219 \pm 162$ & $1265 \pm 188$ & $9.2 \pm 1.0$ & $7.3 \pm 1.3$ & 120 & 462 & $\begin{array}{l}9.36 \\
15.44\end{array}$ & 2.25 \\
\hline IF\&P Fibrosic ${ }^{T M}$ & $\begin{array}{c}28.1 \pm 6.7 \\
53.2 \pm 5.5\end{array}$ & $50.9 \pm 12.0$ & $\begin{array}{l}0.64 \pm 0.12 \\
2.6 \pm 0.2\end{array}$ & $0.71 \pm 0.15$ & & 41 & 0.5 & 0.4 \\
\hline
\end{tabular}
(a) 1991 Production Lot.
(b) 1992 Production Lot.
(c) Composite Strength (Containment Layer, Filtration Mat, And Triaxial Support Braid).
(d) Triaxial Support Braid.
(e) Seam Rupture.
* 15 mm O-Ring Diametral Compressive Strength Or Load.

Table 3. Strength Characterization of the As-Manufactured DuPont PRD-66 Candle Filter Matrix

\begin{tabular}{cccc}
$\begin{array}{c}\text { Temperature, } \\
{ }^{\circ} \mathrm{C}\end{array}$ & $\begin{array}{c}\text { C-Ring Compression, } \\
\text { psi }\end{array}$ & $\begin{array}{c}\text { C-Ring Tension, } \\
\text { psi }\end{array}$ & $\begin{array}{c}\text { O-Ring Compression, } \\
\text { psi }\end{array}$ \\
\hline 25 & $876 \pm 151$ & $874 \pm 79$ & $990 \pm 77$ \\
200 & $914 \pm 138$ & $955 \pm 184$ & $990 \pm 138$ \\
400 & $881 \pm 119$ & $911 \pm 153$ & $1004 \pm 70$ \\
600 & $733 \pm 49$ & $826 \pm 133$ & $1069 \pm 69$ \\
800 & $1009 \pm 118$ & $831 \pm 130$ & $1205 \pm 60$ \\
900 & $1086 \pm 178$ & $878 \pm 143$ & $1171 \pm 97$ \\
1000 & $1092 \pm 65$ & $963 \pm 168$ & $1251 \pm 49$
\end{tabular}

Sample Width: $15 \mathrm{~mm}$. 
Simulated Process Transient Testing. HTHP testing was completed in Westinghouse's PFBC simulator test facility in which a $1.5 \mathrm{~m} 3 \mathrm{M}$ CVI-SiC composite candle, a $1.5 \mathrm{~m}$ DuPont PRD-66 candle filter, a $1.4 \mathrm{~m}$ DuPont SiC-SiC candle filter, and a $1.5 \mathrm{~m} \mathrm{IF \& P}$ Fibrosic ${ }^{T M}$ candle were subjected to seven process transients (i.e., increasing gas temperature excursions ranging from mild to severe), nine maximum severity process transients, ten accelerated pulse cycles, and a final maximum severity process transient. The HTHP PFBC test facility was operated at $843^{\circ} \mathrm{C}$ and $100 \mathrm{psig}$, and during conduct of the maximum severity transients, temperature along the outer surface of the filter elements decreased by $110^{\circ} \mathrm{C}$ and $240^{\circ} \mathrm{C}$ within the first 5 and 60 seconds, respectively, after initiation of the transient. ${ }^{(2)}$ After each transient, a rapid reheat was conducted in order to return the process operating temperature to $843^{\circ} \mathrm{C}$ within one hour after transient initiation.

With the exception of the DuPont SiC-SiC candle, all filters remained intact. The seam which ran along the entire length of the DuPont SiC-SiC candle filter partially opened (i.e., $<1 \mathrm{~mm}$ gap; $\sim 40 \mathrm{~cm}$ rupture length), permitting fines to penetrate through, and to be released into the offgas stream (Figure 2). During handling the candle fractured into two segments.

Accelerated Pulse Cycling. In order to identify the viability and thermal fatigue resistance of the advanced, second generation filter elements, all four filter element types (i.e., 3M CVI-SiC composite candle; DuPont PRD-66 candle; DuPont SiC-SiC candle; and IF\&P Fibrosic ${ }^{\mathrm{TM}}$ candle) were subjected to accelerated pulse cycling. The pulse cycle that was delivered to the array was representative of the conditions which have commonly been used during field operation of $\underline{\mathrm{W}}$-APF systems.

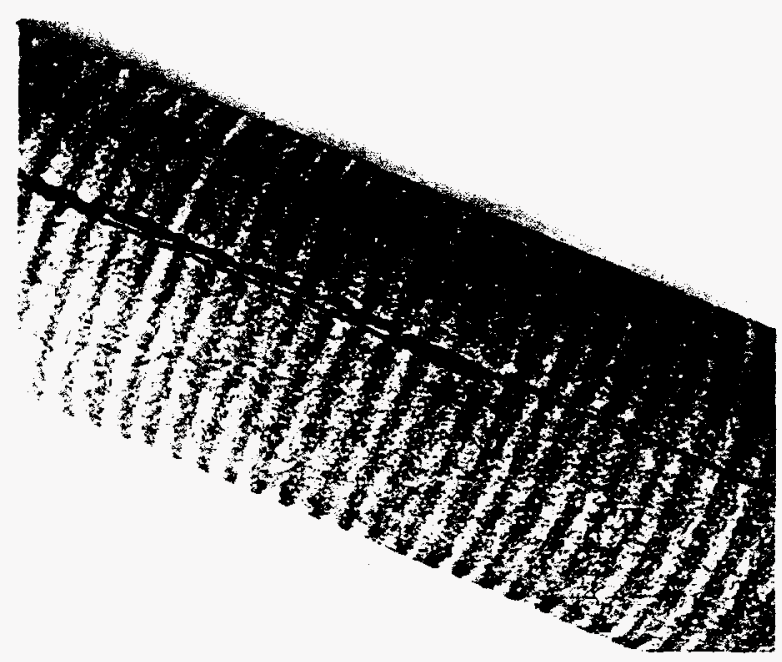

Figure 2. Ruptured Seam of the DuPont SiC-SiC Composite Candle Filter After Process Transient Testing

HTHP testing was conducted at temperatures of $843^{\circ} \mathrm{C}$ and pressures of $100 \mathrm{psig}$, with a pulse cycle delivered every 2.5 minutes. After 1645 pulse cycles, dust was detected in the off-gas, indicating that a breach had occurred within the filter system. Upon disassembly, the IF\&P Fibrosic ${ }^{\mathrm{TM}}$ candle was observed to have fractured along the mid-body (Figure 3). A large hole ( $\sim 75 \mathrm{~mm}$ long; $\sim 40 \mathrm{~mm}$ wide) was evident below the flange, and a smaller through-wall hole (i.e., $\sim 10 \mathrm{~mm}$ ) was evident along the filter body. The longitudinal fractured surface of the Fibrosic ${ }^{\top M}$ matrix followed what appeared to be the "barklike" or matrix texture lines that were apparent along the outer surface of the filter element.

Striated layers of the chopped fiber matrix were evident throughout the fractured IF\&P Fibrosic ${ }^{T M}$ filter wall.

Gas flow "stream" lines were evident along the ID wall of the fractured IF\&P Fibrosic ${ }^{\mathrm{TM}}$ candle. These lines which were approximately $180^{\circ}$ from the large hole that resulted below the flange, were considered to have resulted from repeated pulse cycling. Further inspection of the ID surface near the flange indicated that the surface of the infiltrate 



Figure 3. Fractured IF\&P Fibrosic ${ }^{\Upsilon M}$ Candle Filter After 1645 Accelerated Pulse Cycles Under HTHP Conditions

that was used to provide additional strength along the flange had partially separated from the support matrix.

After removal of the failed IF\&P Fibrosic ${ }^{\top M}$ filter element from the HTHP array, testing was reinitiated, and continued until 3514 pulse cycles had been delivered to the array. Subsequently ash was fed for an additional eight hours in order to develop a dust cake along the outer surface of each of the remaining filter elements. Post-test inspection indicated that with the exception of the 3M CVI-SiC composite filter, all of the remaining filter elements were intact. Failure at the base of the flange of the 3M CVI-SiC composite matrix resulted from extended pulse cycling which partially dislodged the primary gasket seal from its original position in the filter holder mount.

\section{Corrosion Testing}

Westinghouse has previously demonstrated the relative thermal/chemical stability of the oxide- based alumina/mullite filter matrix during exposure to high temperature, oxidizing conditions which contain gas phase alkali and steam. ${ }^{(3-5)}$ In order to demonstrate the stability of the oxide-based DuPont PRD-66 and IF\&P Fibrosic ${ }^{\mathrm{TM}}$ materials, PRD-66 mini-candles which were manufactured with an $-75 \mathrm{~mm}$ section of open filtration area, and $70 \mathrm{~mm}$ diameter $\times 6.4 \mathrm{~mm}$ thick membrane coated IF\&P discs were exposed for 400 hours at $870^{\circ} \mathrm{C}$ to $5-7 \%$ steam/air and $20 \mathrm{ppm} \mathrm{NaCl} / 5-7 \%$ steam/air flow-through testing. During the 400 hour exposure, both the mini-candles and filter discs were subjected to pulse cycling at every 20 minute intervals.

High temperature, flow-through testing was similarly conducted for the nonoxide-based, advanced, second generation filters using minicandles of the 3M CVI-SiC composite matrix, and discs of the DuPont SiC-SiC composite matrix. Post-test characterization of each material has included C-ring compression testing at $870^{\circ} \mathrm{C}$ of the as-manufactured and flow-through tested mini- 
candles, and 4-point bend, 1/4-point flexural strength testing at $870^{\circ} \mathrm{C}$ of the as-manufactured and flow-through tested filter discs. SEM/EDAX analyses are also being performed. A description of the resulting exposed filter matrices, and currently available test results are presented in the following sections.

3M CVI-SiC Composite Matrix. The 3M CVI-SiC composite filter consists of three layers -an outer open mesh confinement layer, a middle filtration mat, and an inner triaxial braided fabric layer which forms the structural support matrix of the filter element. Within the confinement and filtration mat layers, an -1-2 $\mu \mathrm{m}$ layer of silicon carbide encapsulates Nextel ${ }^{\mathrm{TM}} 312$ or aluminabased fibers, while an $\sim 100 \mu \mathrm{m}$ layer of silicon carbide is deposited along the Nextel ${ }^{\mathrm{TM}} 312$ triaxial braid in the support matrix.

After exposure to either the high temperature steam/air or alkali/steam/air flow-through environment, the $3 \mathrm{M}$ mini-candles appeared to be intact, retaining their initial configuration. What was readily apparent, however, was the very brittle nature of the outer confinement layer along the alkali/steam/air-exposed 3M CVI-SiC composite matrix. In several locations, the fiber bundles of the confinement layer weave were broken or missing.

During preparation of the 3M CVI-SiC matrix for strength testing, two as-manufactured minicandles were cut into 15 or $25.4 \mathrm{~mm}$ sections for high temperature C-ring compression testing. These sections were removed from the open filtration area of the mini-candle. Similarly, a $25.4 \mathrm{~mm}$ O-ring section was removed from the reinforced filter matrix directly below the flange. All three layers of the as-manufactured 3M CVI$\mathrm{SiC}$ composite matrix remained bonded together during preparation of either the 15 and $25.4 \mathrm{~mm}$ C-ring, or $25.4 \mathrm{~mm}$ O-ring samples.
Similar C-ring and O-ring samples were removed from the steam/air and alkali/steam/airexposed 3M CVI-SiC mini-candles. During sample preparation, the three composite layers of the steam/air-exposed 3M CVI-SiC matrix remained bonded together, while debonding occurred along both the 15 and $25.4 \mathrm{~mm}$ C-ring sections that were removed from the alkali/steam/air-exposed 3M filter matrix.

What was also apparent for both the steam/air and alkali/steam/air-exposed 3M mini-candles was the extreme difficulty that was encountered during cutting of the reinforced matrix directly below the flange. As shown in Table 4, the applied compressive load required to fail the flange reinforced O-ring sections, and the resulting diametral strength generally decreased after the 3M CVI-SiC composite matrix was exposed for 400 hours at temperatures of $870^{\circ} \mathrm{C}$ to either the steam/air or alkali/steam/air flow-through environment.

As shown in Table 5, the applied compressive load required to fail $\mathrm{C}$-rings that were removed from the 3M CVI-SiC composite filtration area, and the resulting strength also decreased after 400 hours of exposure in the $870^{\circ} \mathrm{C}$ steam/air or alkali/steam/air flow-through environment. The resulting load vs deflection curves that were generated during C-ring compression testing tended to indicate that a reduction in the fracture toughness of the embrittled, 3M CVI-SiC composite matrix resulted after exposure at high temperature to the steam/air and alkali/steam/air test conditions.

Preliminary SEM/EDAX analyses of the steam/air and alkali/steam/air-exposed 3M CVI$\mathrm{SiC}$ filter matrices indicated that the $-1-2 \mu \mathrm{m} \mathrm{SiC}$ layer which had been deposited within the outer confinement layer and triaxial braid support fiber bundles, and along the alumina-based filtration mat fibers, had generally been removed. The $\sim 100 \mu \mathrm{m}$ 


\section{Table 4. Diametral Compressive Strength of the 3M CVI-SiC Composite Mini-Candle Reinforced Flange}

\begin{tabular}{lccccc} 
Filter ID No. & Exposure & $\begin{array}{c}\text { Time, } \\
\text { Hrs }\end{array}$ & $\begin{array}{c}\text { Temp., } \\
{ }^{\circ} \mathrm{C}\end{array}$ & $\begin{array}{c}\text { Doad, } \\
\text { lbs }\end{array}$ & $\begin{array}{c}\text { Strength, } \\
\text { psi }\end{array}$ \\
\hline $3 M-453707$ & As-Manufactured $(25.4 \mathrm{~mm})$ & --- & -- & 30.5 & 2247 \\
$3 \mathrm{M}-453715$ & As-Manufactured $(25.4 \mathrm{~mm})$ & -- & --- & 32.7 & 1907 \\
$3 \mathrm{M}-453710$ & Steam/Air $(25.4 \mathrm{~mm})$ & 400 & 870 & 19.9 & 1975 \\
$3 \mathrm{M}-453708$ & Alkali/Steam/Air $(25.4 \mathrm{~mm})$ & 400 & 870 & 18.5 & 1375 \\
\hline
\end{tabular}

Table 5. Strength Characterization of the Steam/Air and Alkali/Steam/Air-Exposed 3M CVI-SiC Composite Mini-Candles

\begin{tabular}{|c|c|c|c|c|c|c|}
\hline \multirow[t]{2}{*}{ Filter ID No. } & \multirow[t]{2}{*}{ Exposure } & \multirow{2}{*}{$\begin{array}{c}\text { Time, } \\
\text { Hrs }\end{array}$} & \multirow{2}{*}{$\begin{array}{l}\text { Temp., } \\
{ }^{\circ} \mathrm{C}\end{array}$} & \multirow{2}{*}{$\begin{array}{l}\text { Compressive } \\
\text { Load, Ibs }\end{array}$} & \multicolumn{2}{|c|}{$\begin{array}{c}\text { C-Ring Compressive Strength at } 870^{\circ} \mathrm{C} \text {, } \\
\text { psi }\end{array}$} \\
\hline & & & & & Composite Matrix & Triaxial Support Braic \\
\hline $3 M-453707$ & As-Manufactured $(15 \mathrm{~mm})$ & $\ldots$ & $\cdots$ & $3.3 \pm 0.36$ & $1739 \pm 259$ & $11784 \pm 1476$ (a) \\
\hline $3 M-453715$ & As-Manufactured $(25.4 \mathrm{~mm})$ & --- & --- & $4.0 \pm 0.14$ & $1183 \pm 78$ & $8561 \pm 463(a)$ \\
\hline $3 M-453710$ & Steam/Air(15 mm) & 400 & 870 & $2.10 \pm 0.62$ & $987 \pm 250$ & $8533 \pm 1546$ (a) \\
\hline $3 M-453708$ & Alkali/Steam/Air(15 mm) & 400 & 870 & 1.7 & 717 (a) & 6298 \\
\hline $3 M-453708$ & Alkali/Steam/Air(25.4 mm) & 400 & 870 & $2.85 \pm 0.64$ & $762 \pm 151$ (a) & $5808 \pm 695$ \\
\hline
\end{tabular}

(a) Calculated Based On Either The Triaxial Support Braid Or Composite Matrix Wall Thickness.

CVI-SiC deposited layer which coated the triaxial support braid was intact, but was enriched with oxygen. Due to the very thin nature of the interface layer that initially coated the Nextel ${ }^{\mathrm{TM}}$ and alumina-based fibers, resolution and identification of its presence in either the as-manufactured or flow-through tested mini-candles could not be made using SEM/EDAX analytical techniques. Aluminum and silicon-rich, micron, nodular formations were evident along the Nextel ${ }^{\mathrm{TM}}$ and alumina-based fibers in all three composite layers of the steam/air-exposed 3M CVI-SiC composite matrix.
DuPont PRD-66 Filament Wound Matrix. The oxide-based, filament wound, DuPont PRD-66 matrix consists of a layered cordierite, mullite, cristobalite, and corundum microstructure. An amorphous phase is also present in the as-manufactured PRD-66 filter matrix. Due to the difference in the thermal coefficient of expansion of mullite, cordierite, and corundum which are present in the PRD-66 matrix, a microcracked structure is formed after high firing.

The "diamond" pattern weave of the polycrystalline refractory oxide-based fibers forms 
the $-7 \mathrm{~mm}$ structural support layer of the DuPont PRD-66 filter matrix. A thin membrane layer is wrapped along the outer surface of the support matrix, producing a light weight, bulk filter element.

After 400 hours of exposure in the $870^{\circ} \mathrm{C}$, steam/air and alkali/steam/air environment, the DuPont PRD-66 mini-candles generally remained intact. However, along the outer membrane surface of the filtration area of the alkali/steam/airexposed mini-candle, numerous longitudinal cracks were evident (Figure 4). In addition, a $1 \mathrm{~cm} \mathrm{x}$ $1.5 \mathrm{~cm}$ section of the membrane and several of the underlying structural support fibers had been removed along the alkali/steam/air-exposed mini-candle.

As shown in Table 6, the high temperature, $\mathrm{C}$-ring compressive strength of the filtration area in the brittle PRD-66 filter matrix appeared to slightly increase after 400 hours of exposure to the steam/air flow-through environment, while a slight decrease in strength was observed after 400 hours of exposure in the alkali/steam/air environment. In contrast virtually no change in strength was observed along the slurry infiltrated flange or end cap areas of the PRD-66 mini-candles after exposure to either the high temperature steam/air or alkali/steam/air environment (Table 7).

\section{DuPont SiC-SiC Composite Matrix. The} DuPont SiC-SiC composite matrix consists of an $-10-20 \mu \mathrm{m}$ silicon carbide layer which is chemically vapor infiltrated (CVI) along an $\sim 2-5 \mu \mathrm{m}$ interface coating layer which encapsulates $-15 \mu \mathrm{m}$ Nicalon ${ }^{\mathrm{TM}}$ fibers. Several issues have been raised as to the oxidative stability of the dual single-ply felt or hybrid (i.e., single-ply felt; single-ply open mesh screen) DuPont SiC-SiC composite matrix, and in particular the stability of the interface coating and Nicalon ${ }^{\top M}$ fibers.
After 400 hours of exposure of the DuPont $\mathrm{SiC}-\mathrm{SiC}$ matrix to either the $870^{\circ} \mathrm{C}$, flow-through, steam/air or alkali/steam/air environment, depletion of the interface coating resulted (Figure 5). A mottled crystalline phase formed along the $\mathrm{SiC}-\mathrm{SiC}$ surface which was identified by EDAX analysis to contain silicon and oxygen (i.e., on a 1:1 atomic percent basis). The $\mathrm{Si}-\mathrm{O}$ phase formed a rather noncontinuous layer along the surface of the SiC-SiC matrix. The presence of gas phase sodium appeared to enhance surface oxidation of the SiC-SiC matrix, leading to areas that were enriched with $\mathrm{SiO}_{2}$. Sorption of sodium into the $\mathrm{SiO}_{\mathrm{x}}$ or $\mathrm{SiO}_{2}$ layer which covered the $\mathrm{SiC}$ $\mathrm{SiC}$ matrix was not detectable by EDAX analysis after 400 hours of exposure of the DuPont composite matrix to the $870^{\circ} \mathrm{C}, 20 \mathrm{ppm}$ $\mathrm{NaCl} /$ steam/air, flow-through environment. Continued exposure may be needed to promote sorption of alkali, and possibly formation of the sodium silicate eutectic phase. In this manner, the relatively inert $\mathrm{SiC}-\mathrm{SiC}$ matrix appears to exhibit a slower oxidation or corrosion rate in comparison to the clay bonded silicon carbide filter materials.

In contrast, the fine grained $\mathrm{SiC}$ membrane coating of the DuPont matrix tended to form a glaze during the high temperature, alkali/steam/air exposure, which reduced gas flow permeability through the filter disc (Figure 6). The glazed surface which was enriched with sodium could conceivably serve as a potential site for collection and adherence of ash fines at process operating temperatures, which may ultimately cause blinding of the filter element surface.

The residual strength of the hybrid DuPont SiC-SiC matrix (i.e., single-ply felt; single-ply open mesh screen) was determined at $870^{\circ} \mathrm{C}$ via 4-point bend, 1/4-point flexural strength testing of bend bars that had been removed from the alkaliexposed filter disc. Approximately $60 \%$ of the asmanufactured strength remained along the surface of the matrix that had been subjected to pulse 



Figure 4. Cracks and Spalled Areas of the OD Surface Membrane of the $400 \mathrm{Hour}, 870^{\circ} \mathrm{C}$, 20 ppm NaCl/5-7\% Steam/Air-Exposed DuPont PRD-66 Filter Matrix

Table 6. Strength Characterization of the Steam/Air and Alkali/Steam/Air-Exposed DuPont PRD-66 Mini-Candles

\begin{tabular}{cccccc} 
Filter ID No. & Exposure & $\begin{array}{c}\text { Time, } \\
\text { Hrs }\end{array}$ & $\begin{array}{c}\text { Temp., } \\
{ }^{\circ} \mathrm{C}\end{array}$ & \multicolumn{2}{c}{ C-Ring Compression At $870^{\circ} \mathrm{C}$} \\
\hline D-282 & As-Manufactured $(15 \mathrm{~mm})$ & --- &.-- & $9.65 \pm 0.72$ & $1352 \pm 135$ \\
D-289 & Steam/Air $(15 \mathrm{~mm})$ & 400 & 870 & $11.88 \pm 0.71$ & $1541 \pm 146$ \\
D-288 & Alkali/Steam/Air $(15 \mathrm{~mm})$ & 400 & 870 & $8.58 \pm 1.70$ & $1093 \pm 265$ \\
\hline
\end{tabular}

Table 7. Strength of the Reinforced Flange and End Cap Sections of the DuPont PRD-66 Mini-Candles After Flow-Through Testing

\begin{tabular}{|c|c|c|c|c|c|c|c|}
\hline \multirow[b]{3}{*}{ Filter ID No. } & \multirow[b]{3}{*}{ Exposure } & \multirow[b]{3}{*}{$\begin{array}{c}\text { Time, } \\
\text { Hrs }\end{array}$} & \multirow[b]{3}{*}{$\begin{array}{l}\text { Temp., } \\
{ }^{\circ} \mathrm{C}\end{array}$} & \multicolumn{4}{|c|}{ Diametral O-Ring Compression } \\
\hline & & & & \multicolumn{2}{|c|}{ Flange } & \multicolumn{2}{|c|}{ End Cap } \\
\hline & & & & $\begin{array}{l}\text { Load, } \\
\text { lbs }\end{array}$ & $\begin{array}{l}\text { Strength, } \\
\text { psi }\end{array}$ & $\begin{array}{l}\text { Load, } \\
\text { lbs }\end{array}$ & $\begin{array}{l}\text { Strength, } \\
\text { psi }\end{array}$ \\
\hline D-282 & As-Manufactured $(25.4 \mathrm{~mm})$ & -- & -- & 81.3 & 2341 & 56.3 & 1625 \\
\hline D-289 & Steam/Air (25.4 mm) & 400 & 870 & 74 & 1997 & 60.5 & 1665 \\
\hline D-288 & Alkali/Steam/Air (25.4 mm) & 400 & 870 & 84.2 & 1819 & 50.5 & 1619 \\
\hline
\end{tabular}


(a)

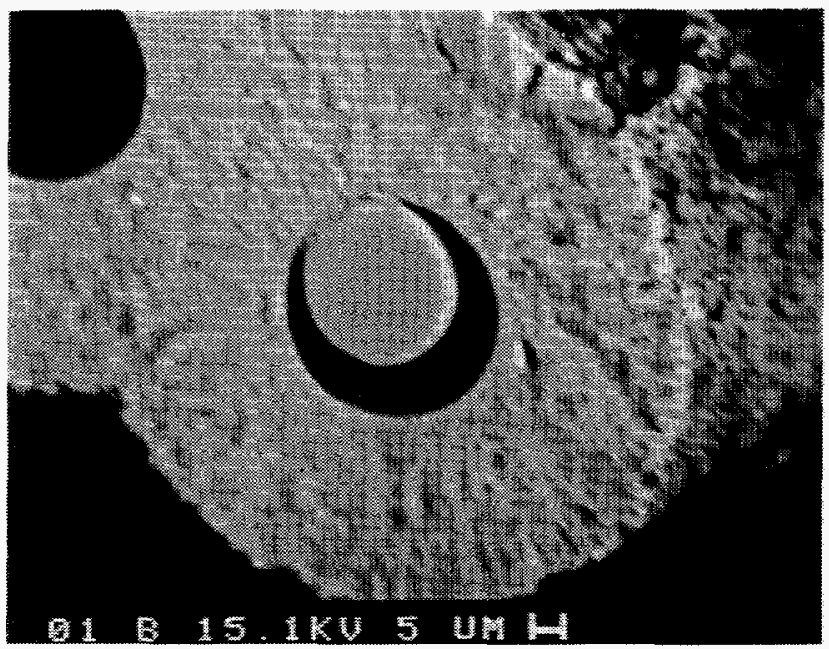

(b)

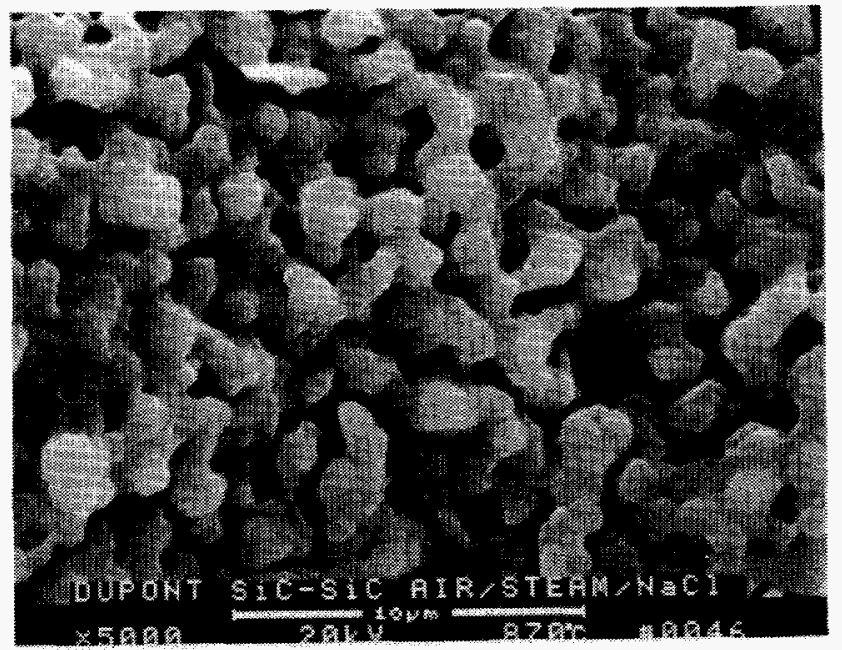

Figure 5. DuPont SiC-SiC Composite Matrix After 400 Hours of Exposure at $870^{\circ} \mathrm{C}$ to the 20 ppm NaCl/5-7\% Steam/Air Flow-Through Test Environment

(a) Depletion of the Interface Coating; (b) Oxidation of the CVI-SiC Surface
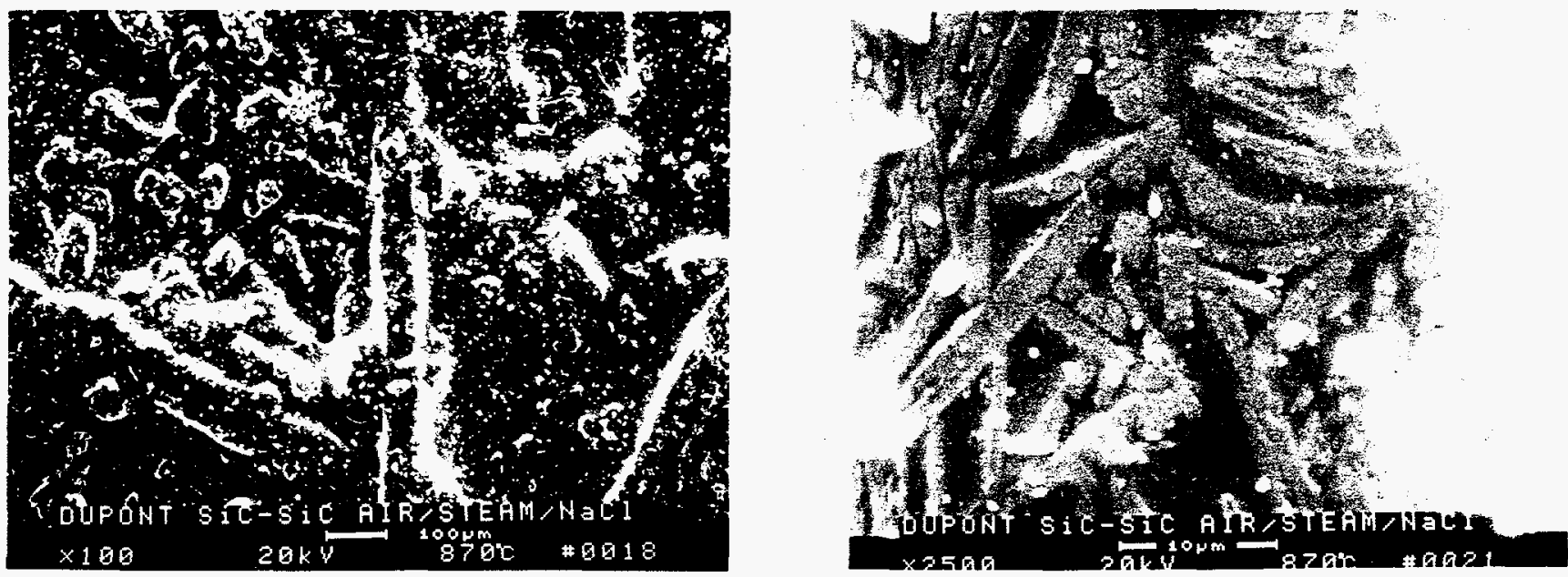

Figure 6. Glazed Sodium-Enriched Surface Membrane of the DuPont SiC-SiC Composite Candle Filter Matrix After 400 Hours of Exposure to $870^{\circ} \mathrm{C}, 20 \mathrm{ppm} \mathrm{NaCl/5-7 \%} \mathrm{Steam} / \mathrm{Air}$ Flow-Through Test Environment 
cleaning, while only $42 \%$ of the as-manufactured strength remained along the membrane coated surface that sorbed alkali during the 400 hour alkali/steam/air, flow-through test exposure (Table 8). Based on the load vs deflection curves that were generated during high temperature, flexural strength testing, the fracture toughness of the low fiber volume, DuPont SiC-SiC filter matrix appeared to decrease after 400 hours of exposure in either the $870^{\circ} \mathrm{C}$ steam/air or alkali/steam/air environment.

IF\&P Fibrosic ${ }^{\mathrm{TM}}$ Filter Matrix. The vacuum infiltrated alumina and aluminosilicate chopped fiber IF\&P Fibrosic ${ }^{\top M}$ matrix was similarly subjected to 400 hours of flow-through testing at $870^{\circ} \mathrm{C}$ in both the steam/air and alkali/steam/air environment. After 400 hours of exposure in the $870^{\circ} \mathrm{C}$ steam/air environment, the membrane coated IF\&P Fibrosic ${ }^{T M}$ disc was torn as the result or repeated pulse cycling (Figure 7). In contrast, the IF\&P Fibrosic ${ }^{T M}$ disc which had been exposed for 400 hours at $870^{\circ} \mathrm{C}$ to the alkali/steam/air environment remained intact, and appeared to have rigidized. SEM/EDAX and XRD analyses will be utilized to differentiate between the resulting phases in the steam/air and alkali/steam/air exposed IF\&P Fibrosic ${ }^{\top M}$ discs.

Four-point bend, 1/4-point flexural testing of the IF\&P filter matrix was intended to be conducted for strength evaluation of the as-manufactured and flow-through tested discs. In order to cut bend bars from the matrix, the asmanufactured filter disc was positioned along a metal support block with double-backed tape, and cut dry with a diamond wheel. Unfortunately during removal of the bend bars, tearing resulted, and further characterization of the asmanufactured and residual strength of the alkali/steam/air-exposed discs was suspended.

In both the flow-through and HTHP accelerated pulse cycle tests, tearing and/or failure of the IF\&P Fibrosic ${ }^{T M}$ vacuum infiltrated, chopped fiber body resulted. During flow-through testing, the pulse gas directly contacted the "nonmembrane" coated surface of the IF\&P Fibrosic ${ }^{\text {TM }}$ matrix, while a baffled plenum prevented direct

Table 8. 4-Point Bend, 1/4-Point Flexural Strength of the Steam/Sir and Alkali/Steam/AirExposed DuPont SiC-SiC Filter Matrix

\begin{tabular}{ccccccc} 
& \multicolumn{2}{c}{$\begin{array}{c}\text { Membrane Tested In } \\
\text { Compression, psi (a) }\end{array}$} & & \multicolumn{2}{c}{$\begin{array}{c}\text { Membrane Tested In } \\
\text { Tension, psi (b) }\end{array}$} \\
\cline { 2 - 3 } \cline { 6 - 7 } Filter Matrix & $25^{\circ} \mathrm{C}$ & $870^{\circ} \mathrm{C}$ & & $25^{\circ} \mathrm{C}$ & $870^{\circ} \mathrm{C}$ \\
\hline As-Manufactured & $13118 \pm 1697$ (c) & $12068 \pm 3128$ (c) & & $7269 \pm 272(\mathrm{c})$ & $4981 \pm 1801$ (c) \\
Steam/Air & NA & $5427 \pm 749$ (d) & & NA & $4450 \pm 541$ (d) \\
Alkali/Steam/Air & NA & $3953 \pm 90$ (d) & & NA & $3092 \pm 304$ (d) \\
Alkali/Steam/Air & NA & $7269 \pm 557$ (c) & & NA & $2106 \pm 454$ (c) \\
\hline
\end{tabular}

Span: 1.57 inch; Cross-Head Speed: $0.02 \mathrm{in} / \mathrm{min}$.

(a) Pulse Cycled Surface Strength; (Open Mesh Screen).

(b) Membrane Coated Surface Strength; (Single-Ply Felt Mat).

(c) Bend Bars Were Cut Paraliel To The Open Mesh Screen Ribs.

(d) Bend Bars Were Cut On A Diagonal To The Open Mesh Screen Ribs.

NA: Not Applicable. 


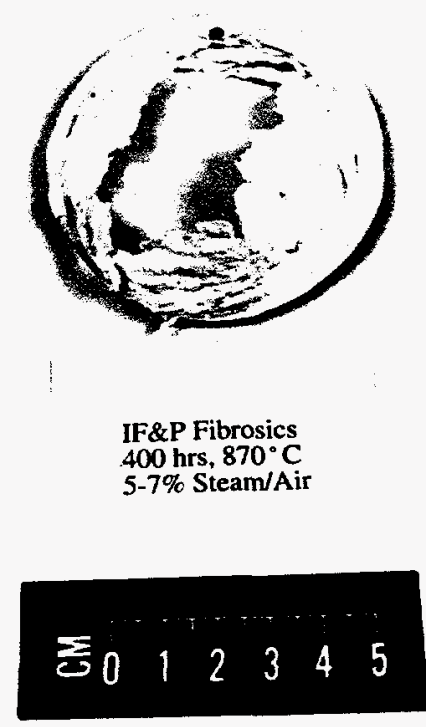

Figure 7. IF\&P Fibrosic ${ }^{\text {TM }}$ Filter Disc After 400 Hours of Exposure at $870^{\circ} \mathrm{C}$ to the 5-7\% Steam/Air Flow-Through Test Environment

impingement of the pulse gas along the ID bore of the filter element during HTHP testing.

\section{Field Testing}

Both 3M CVI-SiC composite and DuPont PRD-66 filament wound candles were installed in the W-APF system at AEP during operation of the 288 candle filter system in Test Segment \#4 and Test Segment \#5 (Table 9). A description of the 3M CVI-SiC and DuPont PRD-66 filter elements after each test segment, and currently available materials analyses are provided in the following sections. The materials characterization results of alternate candle filters (i.e., Schumacher Dia
Schumalith F40; Schumacher Dia Schumalith FT20; Pall Vitropore 442T; and Coors alumina/mullite) that were also installed and operated in the W-APF at AEP are presented elsewhere. ${ }^{(2)}$

3M CVI-SiC Composite Filters. Three 3M $\mathrm{CVI}-\mathrm{SiC}$ composite filters had been initially installed in a middle array in the W-APF in July 1994, and after 1015 hours of operation, two of the elements failed at the base of their flange. The third $3 \mathrm{M}$ filter element, which remained intact and achieved 1705 hours of PFBC test operation prior to termination of Test Segment \#4 at AEP, was recovered for materials characterization. ${ }^{(6)}$

Post-test, room temperature, gas flow resistance measurements of the intact PFBCexposed $3 \mathrm{M}$ filter indicted that the pressure drop across the element was -220 in-wg at a gas face velocity of $10 \mathrm{ft} / \mathrm{min}$. The room temperature pressure drop across the ash coated $3 \mathrm{M}$ filter was relatively high in comparison to alternate filter elements which were exposed to similar PFBC test conditions (i.e., Coors alumina/mullite: 50 in-wg at $10 \mathrm{ft} / \mathrm{min}$ ). The high pressure drop across the $3 \mathrm{M}$ PFBC-exposed candle filter was attributed to the adherence of the dust cake layer along and within the confinement layer, as well as through the filtration mat, and triaxial support braid.

Characterization of the $3 \mathrm{M} \mathrm{CVI-SiC} \mathrm{matrix} \mathrm{via}$ scanning electron microscopy/energy dispersive $\mathrm{x}$-ray analysis indicated that minor changes in the morphology of the filter matrix had occurred after 1705 hours of operation in the $660-760^{\circ} \mathrm{C}$, W-APF system at AEP (Figure 8). Due to deposition of the thin $<1 \mu \mathrm{m}$ interface coating, it was frequently difficult to discern whether the interface coating had remained intact. A gap or separation was considered to exist between the CVI-SiC coating and the underlying Nextel ${ }^{\mathrm{TM}} 312$ fibers in several areas of the PFBC-exposed 3M composite filter matrix. In the high temperature 
Table 9. Summary of the W-PFBC Hot Gas Filter Testing at AEP

\begin{tabular}{cccccc} 
Test Segment & $\begin{array}{c}1 \\
\text { 10/92-12/92 }\end{array}$ & $\begin{array}{c}2 \\
7 / 93-9 / 93\end{array}$ & $\begin{array}{c}3 \\
1 / 94-4 / 94\end{array}$ & $\begin{array}{c}4 \\
7 / 94-10 / 94\end{array}$ & $1 / 95-3 / 95$ \\
\hline Number Of Candles & 384 & 384 & 384 & 288 & 288 \\
Primary Cyclone & In-Service & In-Service & Detuned & Detuned & Inactive \\
Operating Hours & 464.4 & 1295 & 1278.8 & 1705.8 & 1110.4 \\
$\begin{array}{c}\text { Operating } \\
\text { Temperature, }{ }^{\circ} \mathrm{C}\end{array}$ & $730-790$ & $620-790$ & $650-780$ & $660-760$ & $760-845$ \\
$\begin{array}{c}\text { Nominal Face Velocity, } \\
\mathrm{cm} / \mathrm{s}\end{array}$ & $2.4-3.3$ & $2.3-3.3$ & $2.3-3.3$ & $3.0-4.4$ & 4.5 \\
$\begin{array}{c}\text { Inlet Dust Loading, ppmw } \\
\text { Ash Mass Mean, } \mu \mathrm{m}\end{array}$ & 600 & 600 & 3200 & 3200 & 18000 \\
\hline
\end{tabular}

(a)

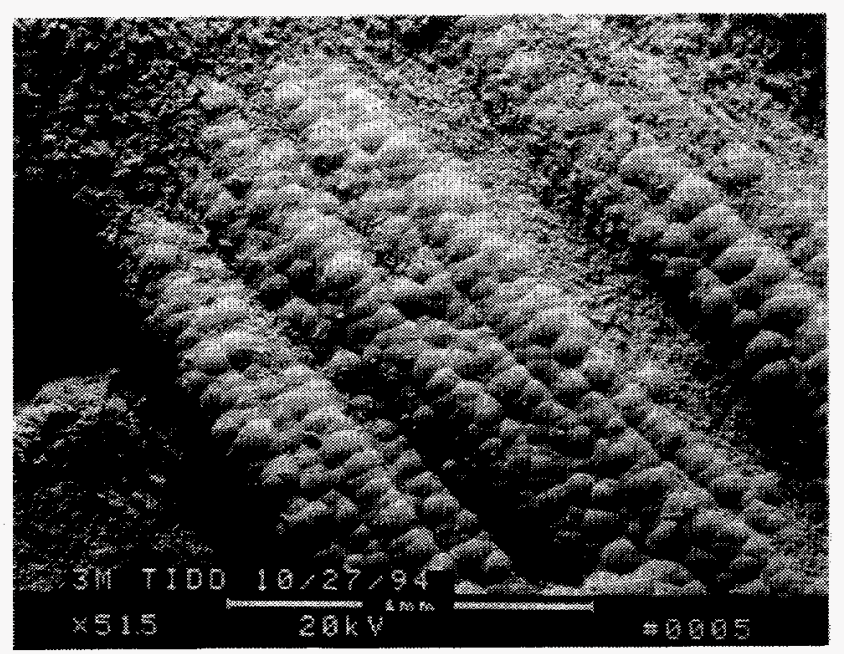

(b)



Figure 8. Morphology of the 3M CVI-SiC Composite Matrix after 1705 Hours of Operation in the $660-760^{\circ} \mathrm{C}$ PFBC Environment 
PFBC environment, oxidation of the interface coating is expected to occur.

Post-test diametral compressive strength testing indicated that the strength of the PFBCexposed 3M CVI-SiC composite matrix was greater than that of the as-manufactured filter matrix (Table 10). Crystallization of the amorphous phase which is initially expected to be present in the as-manufactured Nextel ${ }^{\mathrm{TM}} 312$ fibers, may be responsible for strengthening of the filter matrix. Alternately, due to the accumulation of fines within the PFBC-exposed matrix, "wedging" of fines in between the SiC coated fibers may require a higher load to be applied to the matrix prior to failure, thus generating what appeared to be a strengthened composite matrix. During diametral compressive strength testing, the relatively low load bearing, $732^{\circ} \mathrm{C}$ (i.e., nominal operating temperature), PFBC-exposed, 3M CVI$\mathrm{SiC}$ matrix generally retained the graceful fiber "pull-out" characteristics of the fracture toughened, as-manufactured matrix.

Testing was reinitiated at AEP in January 1995 during which time ten newly manufactured, $3 \mathrm{M}$
CVI-SIC composite filters were installed in the W-APF system. After 1110 hours of filter operation at temperatures ranging between 760 and $845^{\circ} \mathrm{C}$, testing was terminated. Post-test inspection of the filter cluster indicated that all ten of the 3M CVI-SiC composite filter elements were intact. Further inspection of the $3 \mathrm{M}$ candles indicated that ash had been carried into the ID bore of the elements due to a breach within an alternate filter array. As a result, ash fines became tightly packed in the bottom of several of the filter elements. After cool-down of the W-APF, cracks were evident along the internally ash plugged section of at least one filter element (Figure 9). Along an alternate $3 \mathrm{M}$ filter element, a $25.4 \mathrm{~mm}$ diameter hole was evident along the outer confinement layer. The location of the removed confinement layer was $-75 \mathrm{~mm}$ below the flange.

Assuming that the strength of the asmanufactured $3 \mathrm{M}$ filters which were used for testing at Tidd in Test Segment \#5 was equivalent to the strength of the as-manufactured filter elements which were used in Test Segment \#4, strength characterization of the 1110 hour, Tiddexposed 3M CVI-SiC composite filter elements

\section{Table 10. Residual Strength of the 3M CVI-SiC Composite Filter Matrix After Exposure in the W-APF at AEP}

\begin{tabular}{|c|c|c|c|c|c|c|c|c|c|}
\hline \multirow{4}{*}{ Filter ID No. } & \multirow{4}{*}{$\begin{array}{c}\text { Candle } \\
\text { Filter } \\
\text { Location }\end{array}$} & \multirow{4}{*}{$\begin{array}{c}\text { Test } \\
\text { Segment } \\
\text { No. }\end{array}$} & \multirow{4}{*}{$\begin{array}{c}\text { Operating } \\
\text { Time, } \\
\text { Hrs }\end{array}$} & \multicolumn{6}{|c|}{ Diametral O-Ring Testing } \\
\hline & & & & \multicolumn{2}{|c|}{$\begin{array}{l}\text { Room Temperature } \\
\text { Strength, psi }\end{array}$} & \multicolumn{2}{|c|}{$\begin{array}{l}\text { High Temperature }\left(732^{\circ} \mathrm{C}\right) \\
\text { Strength, psi }\end{array}$} & \multicolumn{2}{|c|}{$\begin{array}{l}\text { High Temperature }\left(843^{\circ} \mathrm{C}\right) \\
\text { Strength, psi }\end{array}$} \\
\hline & & & & & Triaxial & & Triaxial & & Triaxial \\
\hline & & & & Composite & Briad & Composite & Braid & Composite & Braid \\
\hline $43-1-2$ & --- & -- & -- & $1341+254$ & $14026 \pm 2012$ & $1060 \pm 219$ & $11012 \pm 1795$ & NA & NA \\
\hline $43-1-6$ & $\mathrm{~B} / \mathrm{M}-15$ & 4 & 1705 & $1696 \pm 195$ & $18220 \pm 1356$ & $1429 \pm 159$ & $15599 \pm 2246$ & NA & NA \\
\hline $45-18-02$ & $\mathrm{C} / \mathrm{T}-18$ & 5 & 1110 & $2333 \pm 415$ & $18975 \pm 3117$ & $2225 \pm 361$ & $18001 \pm 3745$ & $1850 \pm 299$ & $16173 \pm 2245$ \\
\hline
\end{tabular}

NA: Not Available. 


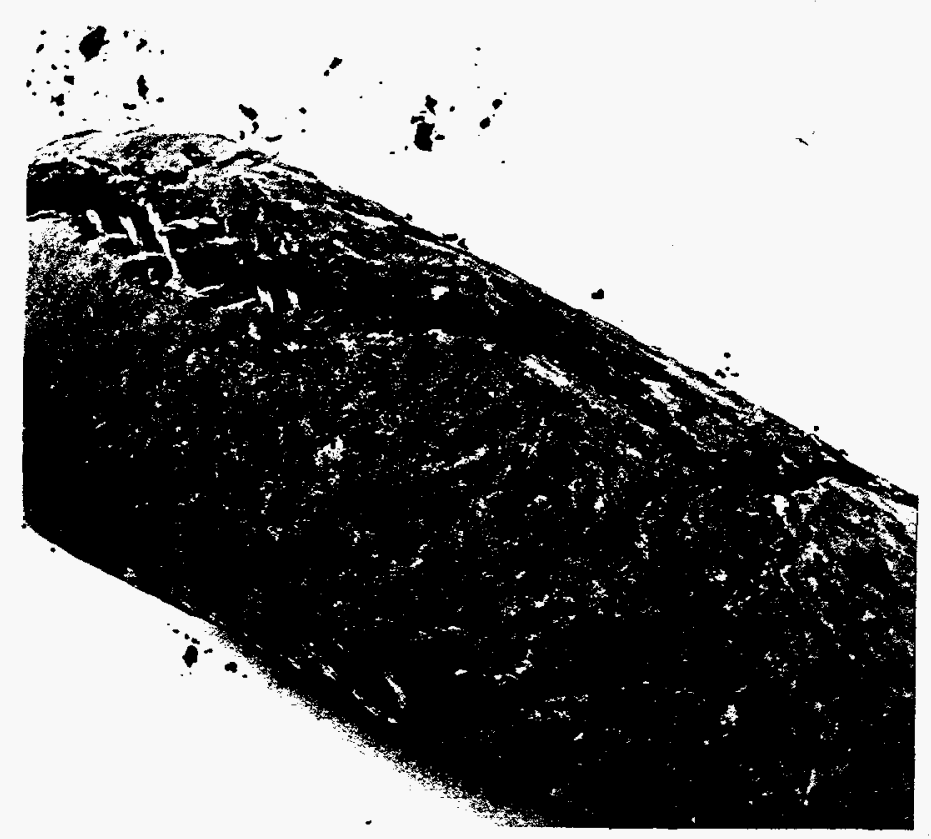

Figure 9. Fractured 3M CVI-SiC Composite Filter End Cap After 1110 Hours of Operation in the W-APF System at AEP in Test Segment \#5

indicated that the ash-filled matrix once again appeared to increase. The shape of the load vs deflection curves generated during high temperature $\mathrm{C}$-ring strength testing are being evaluated to determine the residual fracture toughness of the $3 \mathrm{M} \mathrm{CVI-SiC} \mathrm{composite} \mathrm{filter}$ matrix after 1110 hours of exposure in the elevated temperature PFBC environment.

\section{DuPont PRD-66 Filament Wound Filters.} During operation of the W-APF system in Test Segment \#4, three DuPont PRD-66 filter elements were installed in a middle array. After 1705 hours of operation, all three filters remained intact. During C-ring preparation of the Tidd-exposed PRD-66 filter element, magnesium sulfate recrystallized along the outer surface of the filter, as a result of leaching of the ash that was contained within the filter ID bore and wall during wet cutting with a diamond wheel. Post-test strength characterization of the PRD-66 matrix indicated that the bulk strength of the ash filled matrix tended to increase after 1705 hours of operation at AEP in Test Segment \#4 (Table 11).

Twenty-two DuPont PRD-66 candle filters were installed in a top array for operation in Test Segment \#5. After $\sim 232$ hours of operation, sections of the PRD-66 matrix were identified in the ash hopper discharge, implying that failure had occurred. Testing continued, and after $\sim 775$ hours of operation, additional sections of the PRD-66 filter matrix were evident in the ash hopper discharge.

Testing was terminated after 1110 hours of operation in Test Segment \#5. Post-test inspection of the W-APF internals indicated that ash bridging had been eliminated as the result of completely detuning the primary cyclone. ${ }^{(7)}$ Only two of the DuPont PRD-66 filter elements remained intact, four had suffered either mid-body fracture or failure at a location that was $-3 / 4$ below the flange, and sixteen filters had fractured at the base of each flange. The outer surface of the intact and fractured filters was generally "ash free", particularly along the portion of the body that was adjacent to the plenum pipe, and to approximately mid-way down the length of the filter element. Alternately 1-2 mm of ash was deposited along the outer surface of the PRD-66 candles, near the bottom end cap. "Divot-like" formations resulted in lines which ran parallel down both sides of the remaining intact and fractured filter elements (Figure 10). Localized "divoting" was also observed underneath the outer protected gasket sleeve, as well as in alternate, isolated areas along the filter body. Currently the mechanisms leading to "divoting", flange fracture, and mid-body failure of the DuPont PRD-66 filter elements in Test Segment \#5 are under investigation. Since the PRD-66 filter array had 


\section{Table 11. Residual Strength of the DuPont PRD-66 Filter Matrix After Exposure in the W-APF at AEP}

\begin{tabular}{|c|c|c|c|c|c|c|c|c|c|}
\hline \multirow{3}{*}{$\begin{array}{l}\text { Filter } \\
\text { ID No. }\end{array}$} & \multirow{3}{*}{$\begin{array}{l}\text { Filter } \\
\text { Location }\end{array}$} & \multirow{3}{*}{$\begin{array}{l}\text { Test } \\
\text { Segment } \\
\text { No. }\end{array}$} & \multirow{3}{*}{$\begin{array}{c}\text { Operating } \\
\text { Time, } \\
\text { Hrs }\end{array}$} & \multicolumn{6}{|c|}{ C-Ring Testing } \\
\hline & & & & \multicolumn{2}{|c|}{$\begin{array}{l}\text { Room Temperature } \\
\text { Strength, psi }\end{array}$} & \multicolumn{2}{|c|}{$\begin{array}{l}\text { High Temperature }\left(732^{\circ} \mathrm{C}\right) \\
\text { Strength, psi }\end{array}$} & \multicolumn{2}{|c|}{$\begin{array}{l}\text { High Temperature }\left(843^{\circ} \mathrm{C}\right) \\
\text { Strength, psi }\end{array}$} \\
\hline & & & & Compression & Tension & Compression & Tension & Compression & Tension \\
\hline D-99 & $\ldots$ & -.. & ... & $1219 \pm 162$ & $1265 \pm 188$ & $1277 \pm 178$ & $1304 \pm 327$ & NA & NA \\
\hline D-132 & B/M-7 & 4 & 1705 & $1830 \pm 238$ & $1725 \pm 320$ & $1884 \pm 142$ & $1642 \pm 401$ & NA & NA \\
\hline$D-237$ & $\mathrm{~B} / \mathrm{M}-8$ & 5 & 1110 & $1533 \pm 202$ & $1380 \pm 188$ & $1897 \pm 256$ & $1356 \pm 104$ & $1872 \pm 230$ & $1460 \pm 197$ \\
\hline
\end{tabular}

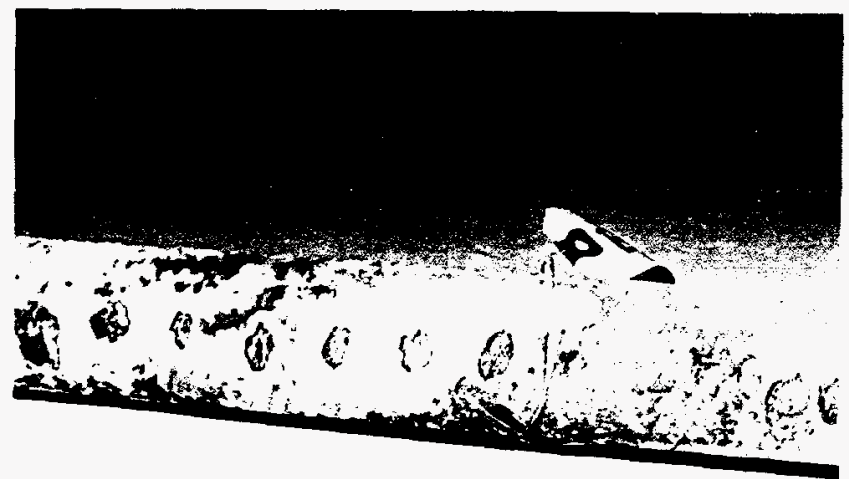

Figure 10. Aligned Divot-Like Formations Along the Surface of the DuPont PRD-66 Candle Filter OD Surface After 1110 Hours of Operation in the W-APF System at AEP in Test Segment \#5

suffered failure after $\sim 232$ hours of operation, ash filled the inside bore of the remaining PRD-66 candles (i.e., $120 \mathrm{~mm}$ and $350 \mathrm{~mm}$ ) during pulse cycling. Failure of the ash-filled PRD-66 end cap region was not observed.

Assuming that the strength of the PRD-66 elements used in Test Segment \#5 was equivalent to the strength of the PRD-66 elements used in Test Segment \#4, post-test strength characterization of the 1110 hour Tidd-exposed
PRD-66 filter matrix indicated that an increase in strength appeared to have occurred along the ashfilled OD surface, while virtually no change in strength was detected along the ID or pulse cycled surface of the filament wound matrix (Table 11).

\section{Comment}

Corrosion and HTHP testing is viewed by Westinghouse as a means to "pre-qualify" a filter element, prior to implementing its use in field test applications. By this means, many of the failure mechanisms described above, can be minimized and/or eliminated.

Although a loss of bulk material strength in the advanced, second generation filter materials generally results during steam/air or alkali/steam/air testing, these results should be viewed solely as a material response which is not influenced by the presence of ash. To date, filter qualification testing has not been focused on demonstrating the impact of ash bridging within a filter array. Bridging may not only be dependent on the size of the ash particles which enter the filter vessel, but may also be dependent on the process operating temperatures which are encountered during field testing, as well as 
system design. Similarly, the resulting dust cake thickness and mechanism of removal are considered to primarily depend on the process operating parameters, coal and sorbent feed, ${ }^{(8)}$ and perhaps the outer surface roughness or finish of each filter element.

\section{FUTURE WORK}

- Complete materials characterization of the filter elements that have been subjected to HTHP accelerated pulse cycling and process transient testing.

- Complete characterization of the minicandles and filter discs that have been exposed to flow-through testing in the $870^{\circ} \mathrm{C}$ steam/air and alkali/steam/air environment.

- Initiate mechanical durability and corrosion testing of the various advanced, second generation filter elements after design, construction and/or compositional modifications have been made by each supplier which potentially reflect improved filter operating reliability and extended service life.

\section{ACKNOWLEDGMENTS}

We wish to acknowledge Mr. Richard Dennis at DOE/METC, as well as Mr. Mike Mudd and Mr. John Hoffman at AEP, for their continued support.

We also wish to acknowledge the efforts of Mr. Bob.Walko for performing the destructive strength testing; Mr. Richard Kunkle for conducting the flow-through corrosion tests; and Mr. Art Fellers, Mr. George Schneider,
Mr. Joe Condle, Mr. Tony Gasparovic, and Mr. John Meyer for participating in the HTHP test program. We also wish to thank Mr. Bob Palmquist and Mr. Tom Mullen for performing the analytical microscopy efforts.

\section{REFERENCES}

1. M. A. Alvin, R. E. Tressler, T. E. Lippert, E. S. Diaz, and E. E. Smeltzer, "Durability of Ceramic Filters," Proceedings of Coal-Fired Power Systems 94 -- Advances in IGCC and PFBC Review Meeting, June 21-23, 1994, Morgantown, WV.

2. M. A. Alvin, T. E. Lippert, E. S. Diaz, and E. E. Smelter, "Thermal and Chemical Stability of Ceramic Candle Filters," Proceedings of Advanced Coal-Fired Power Systems '95 Review Meeting, June 27-29, 1995, Morgantown, WV.

3. M. A. Alvin, R. E. Tressler, T. E. Lippert, E. S. Diaz, "Evaluation of Ceramic Filter Material, Selection for Application," Proceedings of Coal-Fired Power Systems '93 - Contractors Review Meeting, June 28-30, 1993, Morgantown, WV.

4. M. A. Alvin, D. M. Bachovchin, T. E. Lippert, R. E. Tressler, and K. B. McNerney, "Thermal/Chemical Stability of Ceramic Cross Flow Filter Materials," Proceedings of Twelfth Annual Gasification and Gas Stream Cleanup Systems Contractors Review Meeting, September 15-17, 1992, Morgantown, WV.

5. M. A. Alvin, T. E. Lippert, D. M. Bachovchin, and R. E. Tressler, "High Temperature Filter Materials," Proceedings of Coal-Fired Heat Engines, PFBC, and Gas Stream Cleanup Systems Contractors Review Meeting, October 27-29, 1992, Morgantown, WV. 
6. T. E. Lippert and R. A. Newby, "Development and Commercialization of Hot Gas Filters for Power Generation Applications," Proceedings of International Gas Turbine and Aeroengine Congress and Exposition, June 5-8, 1995, Houston, TX.

7. T. E. Lippert, G. J. Bruck, Z. Sanjana, and R. A. Newby, "Westinghouse Advanced Particle Filter System," Proceedings of Advanced Coal-Fired Power Systems '95 Review Meeting, June 27-29, 1995, Morgantown, WV.

8. R. A. Newby, T. E. Lippert, M. A. Alvin, and E. E. Smeltzer, "Filter Cake Characterization Studies," Proceedings of Advanced CoalFired Power Systems '95 Review Meeting, June 27-29, 1995, Morgantown, WV. 